\title{
STUDI POTENSI TERBENTUKNYA CEBAKAN MINERAL RADIOAKTIF PADA BATUAN GRANITIK DI PULAU SULAWESI
}

\section{THE STUDY ON THE POTENTIAL OF RADIOACTIVE MINERAL DEPOSITS FORMATION IN GRANITIC ROCKS IN SULAWESI ISLAND}

\author{
Ngadenin, Widodo, Rachman Fauzi, dan Fadiah Pratiwi \\ Pusat Teknologi Bahan Galian Nuklir - Badan Tenaga Nuklir Nasional \\ ngadenin@batan.go.id
}

\begin{abstract}
ABSTRAK
Di Pulau Sulawesi terdapat banyak batuan granitik yang berpotensi mengandung cebakan mineral radioaktif. Tujuan penelitian ini adalah menentukan tipe cebakan mineral radioaktif berdasarkan karakteristik radioaktivitas, kadar uranium dan mineralogi yang bersumber dari batuan granitik tertentu. Data yang digunakan meliputi pengukuran radioaktivitas, kadar uranium, hasil pengamatan megaskopis dan petrografis batuan serta analisis butir mineral berat batuan granitik hasil eksplorasi uranium di Pulau Sulawesi. Batuan granitik terdiri dari granit, granit biotit, granodiorit, granodiorit biotit, granodiorit hornblenda, granodiorit biotit hornblenda, granodiorit hornblenda biotit, adamelit biotit, adamelit biotit hornblenda, adamelit hornblenda biotit, diorit, diorit hornblenda biotit dan syenit. Radioaktivitas batuan granitik 50 s.d. $1.200 \mathrm{c} / \mathrm{s}$ dan kadar uranium $0,54 \mathrm{~s} . d .36 \mathrm{ppm}$. Mineral radioaktif yang terdapat pada batuan granitik terdiri dari zirkon, monasit, alanit, thorit dan branerit. Cebakan mineral radioaktif yang berpotensi terbentuk di Pulau Sulawesi adalah cebakan thorium tipe placer pada delta dan pantai yang ada saat ini.
\end{abstract}

Kata kunci: cebakan mineral, mineral radioaktif, uranium, thorium, granitik, Sulawesi

\section{ABSTRACT}

In the Island of Sulawesi, there are many granitic rocks which have potential for containing radioactive mineral deposits. The purpose of this study is to determine the type of radioactive mineral deposits based on radioactivity, uranium grade, and mineralogy characteristics of certain granitic rocks. The data used comprise radioactivity measurement, uranium content, megascopic and petrographic observations of rocks, and grain analysis of heavy mineral of granitic rocks from uranium exploration on the island of Sulawesi. The granitic rocks consist of granite, biotite granite, granodiorite, biotite granodiorite, hornblenda granodiorite, hornblenda biotite granodiorite, biotite hornblenda granodiorite, biotite adamelite, hornblenda biotite adamelite, biotite hornblenda diorite, diorite, biotite hornblenda diorite and syenite. The radioactivity of granitic rocks is 50 to $1,200 \mathrm{c} / \mathrm{s}$ and uranium content is 0.54 to $36 \mathrm{ppm}$. Radioactive minerals found in granitic rocks consist of zircon, monazite, alanite, thorite, and branerite. The potential occurrence of radioactive mineral deposits on the island of Sulawesi are placer-type thorium deposits at the modern deltas and coasts.

Keywords: mineral deposits, radioactive minerals, uranium, thorium, granitic, Sulawesi

\section{PENDAHULUAN}

Pulau Sulawesi yang berbentuk unik dan menyerupai bentuk huruf "K" merupakan daerah dengan tektonik yang sangat kompleks karena merupakan tempat pertemuan empat lempeng tektonik yang terdiri dari tiga lempeng besar dan satu lempeng kecil. Tiga lempeng besar yaitu Lempeng Eurasia yang bergerak ke arah selatan-tenggara, Lempeng Pasifik yang bergerak ke arah barat dan Lempeng 
Indo-Australia yang bergerak ke arah utara, sedangkan lempeng kecilnya adalah Lempeng Filipina yang bergerak ke arah selatan - tenggara. Proses tumbukan keempat lempeng tersebut mengakibatkan Pulau Sulawesi mempunyai empat lengan dengan proses tektonik yang berbedabeda, membentuk satu kesatuan mosaik geologi. Pulau ini seolah-olah dirobek oleh berbagai sesar seperti Sesar Palu-Koro, Sesar Matano, Sesar Lawanopo, Sesar Kolaka dan Sesar Walanae. Pada zona tersebut berbagai jenis batuan bercampur sehingga posisi stratigrafinya menjadi sangat unik dan rumit.

Berdasarkan kondisi tektoniknya, Sulawesi dapat dibagi menjadi empat busur, yaitu; busur barat (West \& North Sulawesi Volcano-Plutonic Arc), busur tengah (Central Sulawesi Metamorphic Belt), busur timur (East Sulawesi Ophiolite Belt) dan fragmen benua (micro continents) Blok Banggai - Sula dan Blok Tukang Besi - Buton (Gambar 1). Busur barat memanjang dari lengan utara sampai dengan lengan selatan Pulau Sulawesi. Secara umum merupakan jalur magmatik yang terdiri dari batuan volkanik dan plutonik berumur Paleogen - Kuarter. Sebagai busur magmatik, busur barat dapat dikelompokkan menjadi dua, yaitu jalur utara dan barat. Jalur utara memanjang dari Buol Tolitoli sampai sekitar Manado, dan bagian barat dari Buol Tolitoli ke selatan sampai sekitar Makassar. Batuan jalur utara bersifat riodasitik sampai andesitik, terbentuk pada Miosen - Resen dengan batuan dasar basaltik yang terbentuk pada Eosen Oligosen.

Jalur magmatik bagian barat mempunyai batuan penyusun lebih bersifat kontinen yang terdiri atas batuan gunung api sedimen berumur Mesozoikum - Kuarter dan batuan malihan berumur Kapur. Batuan tersebut diterobos granitoid bersusunan terutama granodioritik sampai granitik.

Busur tengah berupa batuan malihan berumur Kapur yang ditumpangi oleh batuan bancuh sebagai bagian dari Blok Australia. Busur timur berupa ofiolit yang merupakan segmen dari kerak samudera berimbrikasi dan batuan sedimen berumur Trias - Miosen. Busur ini tersusun oleh batuan-batuan mafik dan ultramafik disertai batuan sedimen pelagis dan batuan bancuh di beberapa tempat. Fragmen benua Blok Banggai - Sula merupakan gugusan kepulauan yang terletak di sebelah timur Sulawesi sedangkan fragmen benua Blok Tukang Besi - Buton merupakan gugusan kepulauan yang terletak di tenggara Sulawesi. Fragmen benua Banggai Sula dan Blok Tukang Besi - Buton merupakan pecahan benua yang berpindah dari timur ke arah barat karena strike-slip faults dari New Guinea (Sompotan, 2012; Watkinson, 2011; White et al., 2017) (Gambar 1).

Ditinjau dari aspek metalogenik, di busur barat yang tersusun oleh batuan plutonik dan volkanik berumur Paleogen - Kuarter, di beberapa tempat terdapat cebakan porfiri Cu-Au (Van Leeuwen dan Pieters, 2011; Maulana et al.,2020; Hakim, 2017; Maulana et al., 2013). Pada Busur Tengah yang merupakan jalur kompleks batuan malihan berumur Kapur juga ditemukan daerah prospek cebakan emas di daerah pegunungan Rumbia (Hasria et al., 2017). Busur Timur yang tersusun oleh batuanbatuan mafik dan ultramafik merupakan jalur endapan bijih nikel (Kamaruddin et al., 2018; Lintjewas et al., 2019; Thamsi, 2016). Mineralisasi porfiri $\mathrm{Cu}-\mathrm{Au}$ pada batuan granitik di Sulawesi terdapat di daerah Tombulilato Provinsi Gorontalo, dan daerah Sassak, Mangkaluku, Latuppa dan Palopo Selatan, Provinsi Sulawesi Selatan (Maulana et al., 2013). Di daerah Masamba, Sulawesi Selatan didapatkan mineral radioaktif kelompok thorium yang terdiri dari monasit, zirkon dan thorit pada batuan granitik berumur Tersier (Widodo dan Ngadenin, 2020).

Berdasarkan hasil evaluasi data keterdapatan mineralisasi porfiri $\mathrm{Cu}-\mathrm{Au}$ pada batuan granitik di daerah Tombulilato, Gorontalo dan daerah Sassak, Mangkaluku, Latuppa dan Palopo 
Selatan, Sulawesi Selatan serta keterdapatan mineral radioaktif kelompok thorium pada batuan granitik di daerah Masamba, Sulawesi Selatan maka diharapkan akan diketahui potensi terbentuknya cebakan mineral radioaktif pada batuan granitik di Pulau Sulawesi. Tujuan penelitian ini adalah menentukan tipe cebakan mineral radioaktif yang berpotensi terbentuk berdasarkan karakteristik radioaktivitas dan mineralogi yang bersumber dari batuan granitik tertentu di Pulau Sulawesi.

\section{METODOLOGI}

Data yang digunakan dalam penelitian ini meliputi pengukuran radioaktivitas, kadar uranium, hasil pengamatan mikroskopis dan megaskopis batuan serta hasil analisis butir mineral berat yang diambil dari batuan granitik di busur barat Pulau Sulawesi (Sampurno dkk., 1986; Soetarno dkk., 1983; Sampurno dkk., 1983; Jalil dkk., 1984; Siregar dkk., 1983; Sarwiyana dkk., 1980).

Pengukuran radioaktivitas batuan dilakukan menggunakan detektor sinar gamma SPP 2NF. Nilai radioaktivitas yang terukur merupakan radiasi sinar gamma alami yang berasal dari konsentrasi potassium $(\mathrm{K})$, uranium $(\mathrm{U})$, atau thorium (Th) pada batuan dan unsur nuklida turunannya (Syaeful dkk., 2014). Analisis kadar uranium dilakukan dengan menggunakan alat fluorimeter. Lokasi pengambilan sampel batuan dapat dilihat pada Gambar 2.

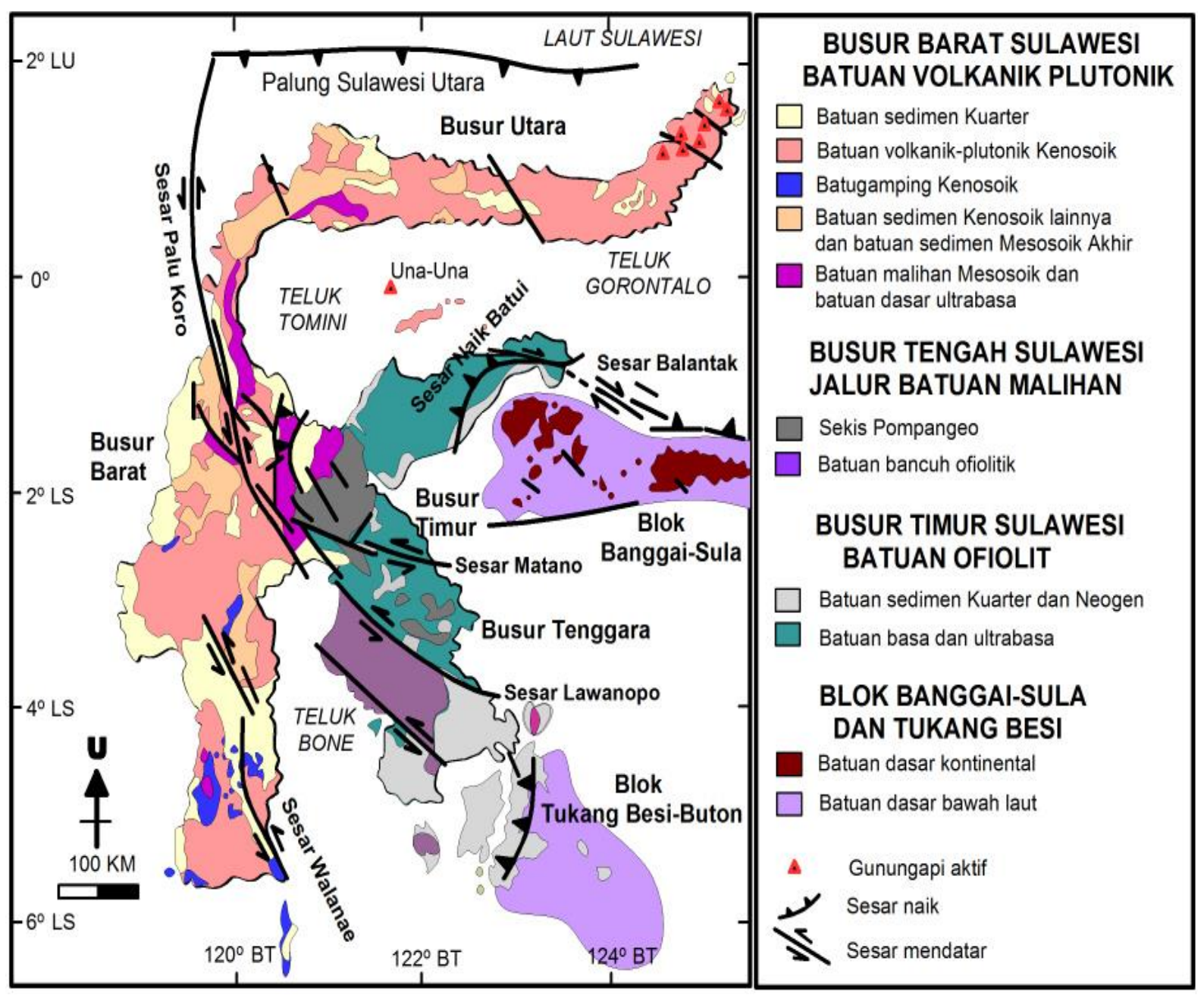

Gambar 1. Peta Busur Tektonik Sulawesi

(Modifikasi dari Sompotan (2012), Watkinson (2011) dan White et al. (2017)) 


\section{MAKALAH ILMIAH}

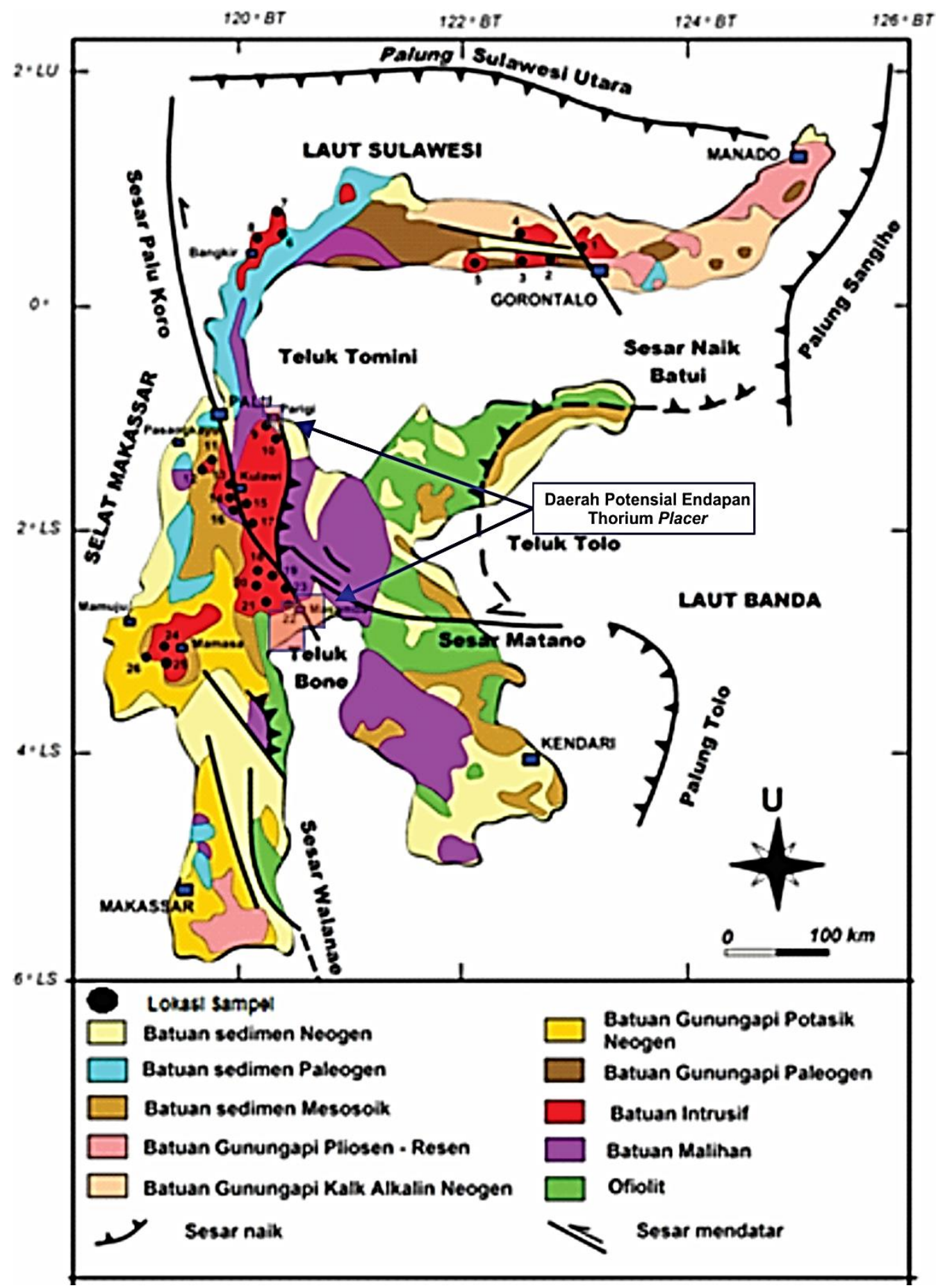

Gambar 2. Peta Geologi Regional Sulawesi modifikasi dari Van Leeuwen dan Pieters (2011) dan Maulana et al. (2020) serta lokasi pengambilan sampel batuan granitik

\section{TEORI PEMBENTUKAN CEBAKAN MINERAL RADIOAKTIF}

Cebakan mineral radioaktif terdiri dari cebakan uranium dan cebakan thorium serta logam tanah jarang. Secara umum cebakan uranium dapat dikelompokkan menjadi 15 tipe yaitu intrusif, granite related, komplek breksi oksida besi polimetalik, volcanic related, metasomatit, metamorfit, ketidakselarasan Proterozoikum, collapse breccia pipe, batupasir, paleo quartz pebble conglomerate, surficial, lignit batubara, karbonat, fosfat dan serpih hitam 
(International Atomic Energy Agency/ IAEA, 2018).

Cebakan uranium tipe intrusif adalah cebakan uranium yang terdapat pada berbagai batuan intrusi seperti granit, pegmatit, monsonit dan syenit peralkalin. Cebakan uranium tipe intrusif dapat berupa cebakan anatektik atau cebakan plutonik. Pada cebakan anatektik batuan pembawa uranium adalah pegmatit dan atau alaskit. Mineral uraninit terdapat pada korok pegmatit granitik dan pegmatit syenitik dalam batuan sedimen atau batuan beku yang termetamorfosakan hingga fasies amfibolit. Umumnya kadar uranium pada cebakan ini adalah rendah (100 s.d. 1.000 ppm) (IAEA, 2018). Kadar minimum untuk penambangan uranium konvensional adalah $0,03 \%$ atau $300 \mathrm{ppm}$ sedangkan untuk penambangan uranium metode in situ leaching (ISL) adalah 0,01\% atau 100 ppm (IAEA, 1998).

Cebakan uranium plutonik terdiri dari tiga kelompok yaitu kelompok monsonit kuarsa, komplek peralkalin dan karbonatit. Cebakan plutonik adalah cebakan yang terkait dengan diferensiasi magmatik. Kadar uranium dan thorium pada cebakan tipe plutonik sangat rendah hingga rendah. Uranium tersebar di berbagai batuan magmatik intrusif. Cebakan ini dikategorikan sebagai unconventional resources oleh IAEA. Di dalam kelompok monzonit kuarsa konsentrasi uranium dengan kadar sangat rendah tersebar merata pada kompleks granitik hingga monzonitik kuarsa pada cebakan porfiri tembaga. Uranium terdapat dalam mineral uraninit atau uranothorianit. Karena kandungan uraniumnya yang sangat rendah ( 20 s.d. 50 ppm), uranium hanya dapat diperoleh sebagai produk sampingan dari pelindian $\mathrm{Cu}-\mathrm{Au}-\mathrm{Mo}$ (IAEA, 2018).

Di dalam kompleks peralkalin, uranium kadar rendah tersebar merata di granit peralkalin atau kubah syenit. Uranium biasanya dijumpai dalam mineral streenstrupin, eudyalit atau monasit. Contoh cebakan tipe ini adalah cebakan uranium di Pocos de Caldas, Brasil. Kadar uranium rendah hingga sangat rendah (5

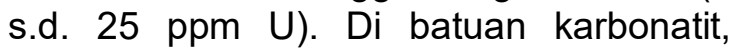
uranium tersebar merata dalam bentuk mineral uranothorianit, perovskit, piroklor, dan mineral yang mengandung unsur tanah jarang dalam kompleks karbonatit. Cebakan uranium tipe ini ditemukan di Phalabora, Afrika Selatan sebagai produk sampingan dari produksi tembaga. Contoh lain dari intrusi karbonatit yang mengandung uranium adalah Araxa dan Catalo, Brasil, dan Sokli, Finlandia. Kadar rata-rata uranium berkisar antara kadar rendah hingga sangat rendah (5 s.d. 20 ppm U) (IAEA, 2018).

Cebakan thorium dan logam tanah jarang dapat dikelompokkan menjadi cebakan primer dan cebakan sekunder (IAEA, 2019). Cebakan primer terdiri dari komplek batuan beku dan terobosan alkali, karbonatit, syenit dan batuan asosiasinya, alkali granit, pegmatit dan urat-urat pada batuan terobosan alkali, korok charnokitleukotonalit, oksida besi dan hidrotermal magmatik, metasomatit derajat tinggi dan cebakan yang belum jelas asalnya. Cebakan sekunder terdiri dari cebakan paleo placer Pra Kambrium dan cebakan placer delta dan pantai saat ini.

\section{HASIL}

Data hasil eksplorasi mineral radioaktif di Sulawesi terdiri dari data pengukuran radioaktivitas, kadar uranium, analisis petrografi dan pengamatan megaskopis batuan pada 25 sampel serta analisis butir mineral berat pada satu sampel pelapukan granit biotit (Tabel 1 dan Gambar 3 s.d. 5). Pengukuran radioaktivitas menggunakan SPP 2NF dilakukan pada sampel - sampel yang mewakili lokasi singkapan yang menunjukkan nilai anomali yang signifikan. 
Tabel 1. Data Hasil Pengukuran Radioaktivitas, Analisis Kadar Uranium, Analisis Petrografi, Analisis Butir Mineral dan Pengamatan Megaskopis di Busur Barat Pulau Sulawesi

(Sampurno dkk., 1986; Soetarno dkk., 1983; Sampurno dkk., 1983; Jalil dkk., 1984; Siregar dkk., 1983; Sarwiyana dkk., 1980)

\begin{tabular}{|c|c|c|c|c|c|}
\hline $\begin{array}{l}\text { Nomor } \\
\text { Sampel }\end{array}$ & Nama Batuan & $\begin{array}{l}\text { Radio } \\
\text { aktivitas } \\
(\mathrm{c} / \mathrm{s})\end{array}$ & $\begin{array}{l}\text { Kadar } \\
\text { Uranium } \\
\text { (ppm) }\end{array}$ & Komposisi Mineral & Keterangan \\
\hline 1 & Granodiorit & 50 & 1,66 & $\begin{array}{l}\text { Plagioklas } 40 \% \text {, K.felspar } 10 \% \text {, } \\
\text { kuarsa } 30 \% \text {, biotit } 9 \% \text {,hornblenda } \\
10 \% \text {, mineral opak } 1 \%\end{array}$ & Analisis Petrografi \\
\hline 2 & $\begin{array}{l}\text { Diorit } \\
\text { hornblenda } \\
\text { biotit }\end{array}$ & 75 & 2,31 & $\begin{array}{l}\text { Plagioklas } 30 \% \text {, kuarsa } 8 \%, \mathrm{~K} \text {. } \\
\text { Felspar } 5 \% \text {, hornblenda } 10 \% \text {, } \\
\text { biotit } 5 \% \text {, masa dasar } 40 \% \text {, } \\
\text { mineral opak } 2 \%\end{array}$ & Analisis Petrografi \\
\hline 3 & Granodiorit & 100 & 1,32 & $\begin{array}{l}\text { K. Felspar } 40 \% \text {, plagioklas } 22 \% \text {, } \\
\text { kuarsa } 23 \% \text {, klorit } 10 \% \text {, mineral } \\
\text { opak } 2 \% \text {, apatit dan titanit } 1 \% \text {, } \\
\text { oksida besi } 2 \% \text {. }\end{array}$ & Analisis Petrografi \\
\hline 4 & $\begin{array}{l}\text { Diorit } \\
\text { hornblenda } \\
\text { biotit }\end{array}$ & 120 & 4,96 & $\begin{array}{l}\text { Plagioklas } 25 \% \text {, hornblenda } \\
7 \% \text {,biotit } 5 \% \text {, piroksen } 2 \% \text {, kuarsa } \\
0,6 \% \text {, mineral opak } 0,4 \% \text {, masa } \\
\text { dasar } 60 \%\end{array}$ & Analisis Petrografi \\
\hline 5 & Granodiorit & 75 & 0,54 & $\begin{array}{l}\text { Kuarsa } 15 \%, \text { K. Felspar } 20 \% \text {, } \\
\text { plagioklas } 51 \% \text {, hornblenda } 4 \% \text {, } \\
\text { biotit } 3 \% \text {, mineral opak } 6 \% \text {, zirkon } \\
\text { dan apatit } 1 \%\end{array}$ & Analisis Petrografi \\
\hline 6 & Adamelit biotit & 180 & 5,66 & $\begin{array}{l}\text { Ortoklas } 38 \% \text {, plagioklas } 22 \% \text {, } \\
\text { kuarsa } 25 \% \text {, biotit } 8 \% \text {, apatit } 2 \% \text {, } \\
\text { mineral opak } 4 \% \text {, zrkon dan } \\
\text { monasit } 1 \%\end{array}$ & Analisis Petrografi \\
\hline 7 & $\begin{array}{l}\text { Adamelit } \\
\text { hornblenda } \\
\text { biotit }\end{array}$ & 200 & 12,47 & $\begin{array}{l}\text { Plagioklas } 30 \% \text {, ortoklas } 29 \% \text {, } \\
\text { kuarsa } 22 \% \text {, hornblenda } 7 \% \text {, } \\
\text { biotit } 6 \% \text {, apatit } 1 \% \text {, zirkon dan } \\
\text { monasit } 1 \% \text {, mineral opak } 2 \% \text {, } \\
\text { oksida besi } 2 \%\end{array}$ & Analisis Petrografi \\
\hline 8 & Granit biotit & 480 & 16,96 & $\begin{array}{l}\text { Ortoklas } 44 \%, \text { kuarsa } 25 \% \text {, } \\
\text { plagioklas } 18 \% \text {, biotit } 7 \% \text {, apatit } \\
1 \% \text {, epidot } 1 \% \text {, titanit } 1 \% \text {, mineral } \\
\text { opak } 3 \%\end{array}$ & Analisis Petrografi \\
\hline 9 & Granit biotit & 400 & 7,58 & $\begin{array}{l}\text { Ortoklas, plagioklas, kuarsa, } \\
\text { biotit, hornblenda, mineral opak }\end{array}$ & $\begin{array}{l}\text { Pengamatan } \\
\text { Megaskopis }\end{array}$ \\
\hline 10 & Granit biotit & 400 & 16,39 & $\begin{array}{l}\text { Ortoklas, plagioklas, } \\
\text { kuarsa, } \\
\text { biotit, hornblenda, mineral opak }\end{array}$ & $\begin{array}{l}\text { Pengamatan } \\
\text { megaskopis }\end{array}$ \\
\hline 11 & Granit & 250 & 11,35 & $\begin{array}{l}\text { Ortoklas } 62 \% \text {, kuarsa } 30 \% \text {, } \\
\text { plagioklas } 5 \% \text {, biotit } 2 \% \text {, monasit } \\
1 \%\end{array}$ & Analisis Petrografi \\
\hline 12 & $\begin{array}{l}\text { Granodiorit } \\
\text { hornblenda }\end{array}$ & 225 & 11,04 & $\begin{array}{l}\text { Plagioklas } 43 \% \text {, ortoklas } 20 \% \text {, } \\
\text { kuarsa } 10 \%, \text { hornblenda } 14 \% \text {, } \\
\text { mineral opak } 6 \% \text {, alanit } 5 \% \text {, apatit } \\
1 \% \text {, zirkon dan monasit } 1 \%\end{array}$ & Analisis Petrografi \\
\hline 13 & $\begin{array}{l}\text { Adamelit biotit } \\
\text { hornblenda }\end{array}$ & 200 & 14,4 & $\begin{array}{l}\text { Ortoklas } 40 \%, \quad \text { plagioklas } 28 \% \text {, } \\
\text { kuarsa } 15 \%, \quad \text { biotit } 10 \% \text {, } \\
\text { hornvblenda } 5 \%, \quad \text { apatit } 1 \% \text {, } \\
\text { mineral opak } 1 \% .\end{array}$ & Analisis Petrografi \\
\hline 14 & $\begin{array}{l}\text { Granodiorit } \\
\text { biotit } \\
\text { hornblenda }\end{array}$ & 400 & 11,11 & $\begin{array}{l}\text { Ortoklas } 10 \% \text {, plagioklas } 45 \% \text {, } \\
\text { kuarsa } 15 \% \text {, biotit } 12 \% \text {, } \\
\text { hornblenda } 6 \% \text {, kalsit } 5 \% \text {, apatit } \\
1 \% \text {, zirkon } 1 \% \text {, klorit } 5 \% \text {, mineral } \\
\text { opak } 4 \% \text {. }\end{array}$ & Analisis Petrografi \\
\hline
\end{tabular}




\begin{tabular}{|c|c|c|c|c|c|}
\hline $\begin{array}{l}\text { Nomor } \\
\text { Sampel }\end{array}$ & Nama Batuan & $\begin{array}{l}\text { Radio } \\
\text { aktivitas } \\
(\mathrm{c} / \mathrm{s}) \\
\end{array}$ & $\begin{array}{l}\text { Kadar } \\
\text { Uranium } \\
\text { (ppm) }\end{array}$ & Komposisi Mineral & Keterangan \\
\hline 15 & $\begin{array}{l}\text { Granodiorit } \\
\text { biotit } \\
\text { hornblenda }\end{array}$ & 400 & 6,40 & $\begin{array}{l}\text { Ortoklas } 10 \% \text {, plagioklas } 45 \% \text {, } \\
\text { kuarsa } 15 \% \text {, biotit } 12 \% \text {, } \\
\text { hornblenda } 6 \% \text {, apatit } 2 \% \text {, } \\
\text { monasit } 1 \% \text {, klorit } 3 \% \text {, spene } 5 \% \text {, } \\
\text { mineral opak } 1 \% \text {. }\end{array}$ & Analisis Petrografi \\
\hline 16 & $\begin{array}{l}\text { Granodiorit } \\
\text { hornblenda } \\
\text { biotit }\end{array}$ & 1200 & 30 & $\begin{array}{l}\text { Kuarsa } 16 \% \text {, plagioklas } 39 \% \text {, } \\
\text { ortoklas } 9 \% \text {, biotit } 9 \% \text {, hornblenda } \\
16 \% \text {, spene } 4 \% \text {, apatit } 2 \% \text {, } \\
\text { monasit+zirkon+thorit } 1 \% \text {, mineral } \\
\text { opak } 4 \% \text {. }\end{array}$ & Analisis Petrografi \\
\hline 17 & Adamelit biotit & 450 & 8,4 & $\begin{array}{l}\text { Kuarsa } 30 \%, \quad \text { ortoklas } \\
26 \% \text {, plagioklas } 30 \% \text {, biotit } 9 \% \text {, } \\
\text { apatit } 2 \% \text {, mineral opak } 2 \% \text {, } \\
\text { zirkon+ monasit+ rutil } 1 \%\end{array}$ & Analisis Petrografi \\
\hline 18 & Granit biotit & 250 & 30,92 & $\begin{array}{l}\text { Kuarsa } 15 \% \text {, Plagioklas } 18 \% \text {, } \\
\text { K.Felspar } 50 \% \text {, biotit } 12 \% \text {, titanit } \\
3 \% \text {, apatit+zirkon } 1 \% \text {, mineral } \\
\text { opak } 1 \%\end{array}$ & Analisis Petrografi \\
\hline 19 & Granit biotit & 300 & 12,38 & $\begin{array}{l}\text { Kuarsa } 15 \%, \text { ortoklas } 26 \% \text {, } \\
\text { plagioklas } 45 \% \text {, biotit } 10 \% \text {, } \\
\text { muskovit } 1 \% \text {, fluorit } 1 \% \text {, mineral } \\
\text { opak } 1 \% \text {, zirkon+apatit } 1 \%\end{array}$ & Analisis Petrografi \\
\hline 20 & $\begin{array}{l}\text { Granodiorit } \\
\text { biotit }\end{array}$ & 200 & 12,31 & $\begin{array}{l}\text { Kuarsa } 20 \% \text {, plagioklas } 45 \% \text {, } \\
\text { K.Felspar } 15 \% \text {, biotirt } 15 \% \text {, titanit } \\
3 \% \text {, zirkon+apatit } 1 \% \text {, mineral } \\
\text { opak } 1 \%\end{array}$ & Analisis Petrografi \\
\hline 21 & Granit Biotit & 300 & 19,9 & $\begin{array}{l}\text { Kuarsa } 12 \% \text {, plagioklas } 20 \% \text {, } \\
\text { ortoklas } 55 \% \text {, biotit } 10 \% \text {, epidot } \\
1 \% \text {, zirkon } 1 \% \text {, mineral opak } 1 \% \text {. }\end{array}$ & Analisis Petrografi \\
\hline 22 & $\begin{array}{l}\text { Adamelit biotit } \\
\text { hornblenda }\end{array}$ & 200 & 9,68 & 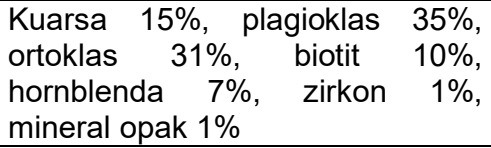 & Analisis Petrografi \\
\hline 23 & Granit biotit & 350 & 7,26 & $\begin{array}{l}\text { Monasit, zirkon, apatit, ilmenit, } \\
\text { titanit, alanit, branerit, thorit }\end{array}$ & $\begin{array}{l}\text { Analisis Butir } \\
\text { Mineral Berat }\end{array}$ \\
\hline 24 & Diorit & 250 & 3,7 & $\begin{array}{l}\text { Plagioklas , hornblenda, biotit } \\
\text { piroksen, mineral opak }\end{array}$ & $\begin{array}{c}\text { Pengamatan } \\
\text { megaskopis }\end{array}$ \\
\hline 25 & Granit & 240 & 7,7 & $\begin{array}{l}\text { Ortoklas, plagioklas, kuarsa, } \\
\text { biotit, mineral opak }\end{array}$ & $\begin{array}{l}\text { Pengamatan } \\
\text { megaskopis }\end{array}$ \\
\hline 26 & Syenit & 750 & 36 & $\begin{array}{l}\text { Ortoklas, plagioklas, biotit, } \\
\text { kuarsa, mineral opak }\end{array}$ & $\begin{array}{l}\text { Pengamatan } \\
\text { megaskopis }\end{array}$ \\
\hline
\end{tabular}
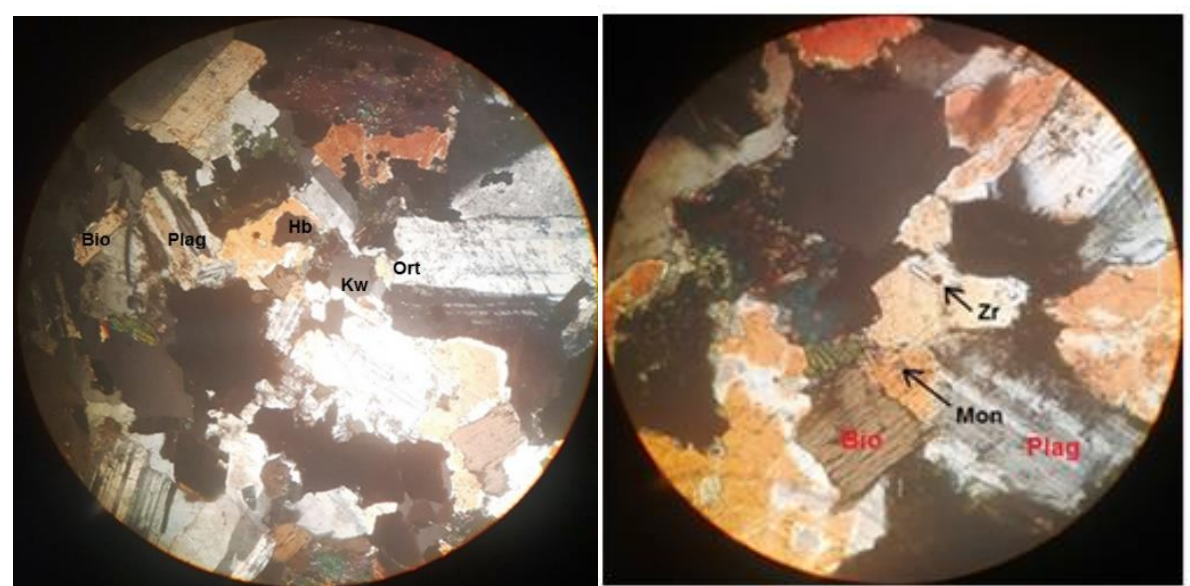

Gambar 3. Foto sayatan tipis batuan sampel nomor 7. Keterangan: Bio $=$ biotit, $\mathrm{Plag}=$ plagioklas, $\mathrm{Kw}=$ kuarsa, $\mathrm{Hb}=$ hornblenda, Ort = ortoklas, $\mathrm{Zr}=$ zirkon, $\mathrm{Mon}=$ monasit 


\section{MAKALAH ILMIAH}
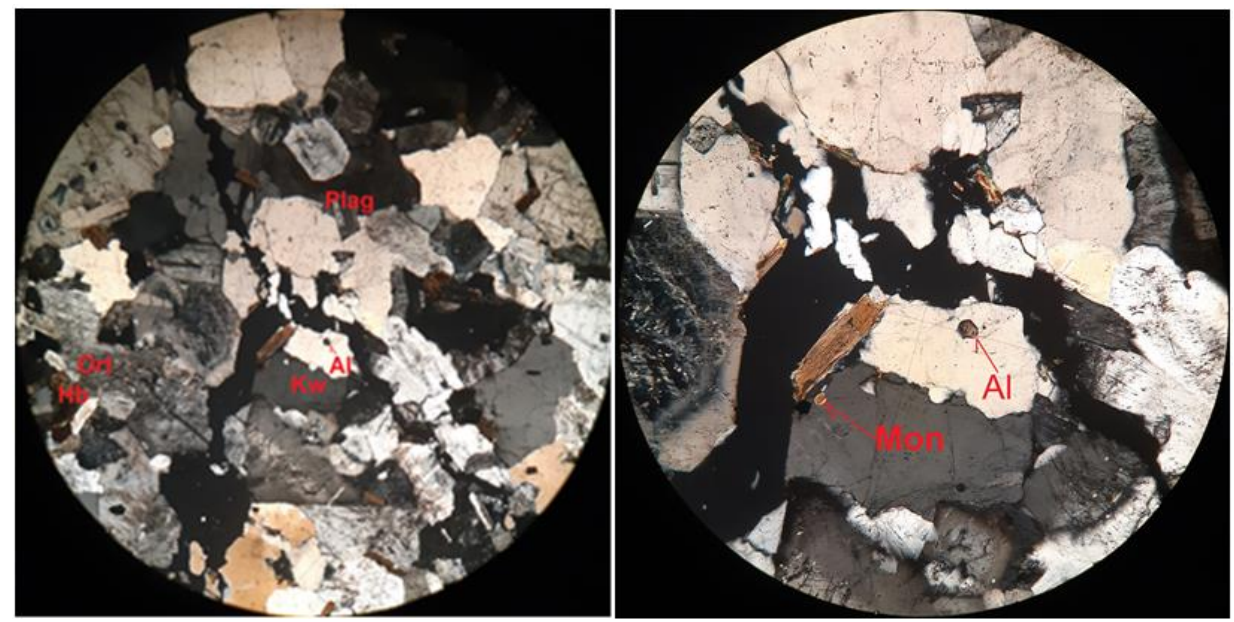

Gambar 4. Foto sayatan tipis batuan sampel nomor 12. Keterangan: Plag = plagioklas, $\mathrm{Kw}=$ kuarsa, $\mathrm{Hb}=$ hornblenda, Ort = ortoklas, Mon = monasit, $\mathrm{Al}=$ alanit

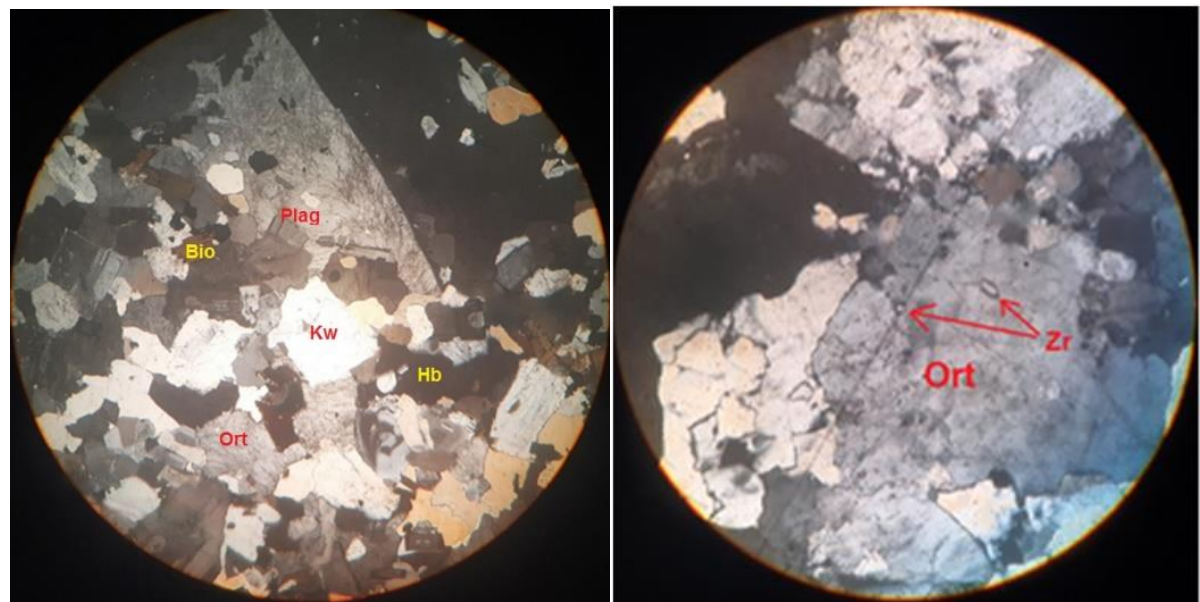

Gambar 5. Foto sayatan tipis batuan sampel nomor 16. Keterangan: Bio = biotit, Plag = plagioklas, $\mathrm{Kw}=$ kuarsa, $\mathrm{Hb}=$ hornblenda, Ort = ortoklas, $\mathrm{Zr}=$ zirkon

\section{PEMBAHASAN}

Dari 15 tipe cebakan uranium dan 12 tipe cebakan thorium yang ada (Bruneton, 2014), jenis cebakan yang berpotensi terbentuk pada batuan granitik di Sulawesi adalah cebakan uranium tipe intrusif (intrusive deposits) serta cebakan thorium tipe placer. Cebakan uranium tipe intrusif dapat dikelompokkan menjadi dua yaitu cebakan subtipe pegmatit alaskit anatektik dan cebakan subtipe plutonik.

\section{Cebakan Uranium Tipe Intrusif - Subtipe Pegmatit Alaskit Anatektik}

Batuan pembawa uranium untuk cebakan pegmatit alaskit anatektik adalah alaskit (leukogranit). Mineral radioaktif yang terdapat dalam alaskit adalah uraninit dengan kadar uranium 100 s.d. 1.000 ppm (IAEA, 2018). Alaskit atau leukogranit merupakan granit tipe $S$ yaitu granit yang terbentuk dari hasil pelelehan sebagian batuan para metamorfik (Zhao et al., 2011), atau pelelehan dari batuan meta sedimen (Zhang et al., 2019), atau hasil anateksis batuan pelitik (Zhao et al., 2013), secara mineralogi alaskit umumnya berupa granit dua mika (Zhao et al., 2011; Zhang et al., 2019; Zhao et al., 2013). Beberapa penulis menyimpulkan bahwa granit di busur barat Pulau Sulawesi adalah granit tipe I (Maulana et al., 2016). Granit Masamba dan Mamasa merupakan granit tipe I (Maulana et al., 2016; Kurniady dkk., 2019). 
Batuan pembawa uranium pada batuan granitik di Pulau Sulawesi terdiri dari granit, granodiorit, diorit, adamelit dan syenit. Mineral radioaktif terdiri dari zirkon, monasit, alanit, thorit dan branerit (Tabel 1). Kadar uranium $0,54 \mathrm{ppm}$ s.d. $36 \mathrm{ppm}$. Dengan melihat indikator batuan pembawa uranium bukan alaskit serta tidak ditemukannya uraninit dan kadar uraniumnya dibawah 100 ppm maka dapat dinyatakan bahwa di Pulau Sulawesi tidak berpotensi terbentuk cebakan tipe intrusif subtipe pegmatit alaskit anatektik.

\section{Cebakan Uranium Tipe Intrusif - Subtipe Plutonik}

Cebakan uranium tipe intrusif - subtipe plutonik dibagi menjadi tiga kelompok yaitu kelompok monsonitik kuarsa, komplek peralkalin dan karbonatit. Batuan pembawa uranium untuk kelompok monzonit kuarsa adalah batuan granitik hingga monsonitik kuarsa yang terdapat pada cebakan porfiri tembaga, kadar uranium sangat rendah (20 s.d. 50 ppm). Mineral indikatornya adalah uraninit atau uranothorianit (IAEA, 2018). Pada cebakan uranium tipe intrusif - subtipe plutonik - kelompok monsonit kuarsa, uranium merupakan produk samping dari cebakan tembaga porfiri.

Batuan granitik di Sulawesi terdiri dari granit, granodiorit, diorit, adamelit dan syenit (Tabel 1). Kadar uranium 5,66 s.d. $36 \mathrm{ppm}$. Mineral radioaktif terdiri dari zirkon, monasit, alanit, thorit dan branerit. Menurut penelitian terdahulu pada beberapa tempat pada batuan granitik di Sulawesi terdapat mineralisasi tembaga porfiri yaitu di daerah Sassak, Mangkaluku, Latuppa dan Palopo Selatan, Sulawesi Selatan (Maulana et al., 2013).

Walaupun terdapat mineralisasi tembaga porfiri pada batuan granitik di Pulau Sulawesi dengan kadar uranium yang memenuhi syarat antara lain granit biotit pada sampel nomor 18 dengan kadar $30,92 \mathrm{ppm}$ dan syenit pada sampel nomor 26 dengan kadar 36 ppm (Tabel 1 dan
Gambar 2), tetapi tidak terdapat mineral uraninit atau uranothorianit sebagai mineral indikator pembentukan cebakan. Dengan demikian dapat disimpulkan bahwa cebakan uranium kelompok monzonit kuarsa tidak berpotensi terbentuk di Sulawesi.

Batuan pembawa uranium pada kelompok kompleks peralkalin, adalah granit peralkalin atau kubah syenit. Kadar uranium rendah hingga sangat rendah (5 s.d. $25 \mathrm{ppm} U$ ). Uranium biasanya dijumpai dalam mineral streenstrupin, eudyalit atau monasit (IAEA, 2018). Syenit dengan kadar uranium 36 ppm ditemukan di daerah Mamasa, Sulawesi Barat. Menurut penelitian terdahulu batuan granitik di daerah Mamasa merupakan granit tipe I. Tidak ditemukan mineral monasit sebagai salah satu mineral indikator radioaktif pada cebakan ini. Mineral radioaktif yang terdapat pada granit Mamasa adalah zirkon dan alanit (Maulana et al., 2014). Walaupun terdapat syenit dengan kadar 36 ppm sebagai batuan pembawa uranium di daerah Mamasa tetapi karena tidak terdapat monasit sebagai mineral indikator maka cebakan uranium tipe intrusif - subtipe plutonik - kelompok komplek peralkalin tidak berpotensi terbentuk pada batuan granitik yang tersebar di daerah Mamasa, Sulawesi Barat.

Di kelompok karbonatit, batuan pembawa uranium adalah karbonatit yaitu batuan beku dengan komposisi mineral karbonat terutama kalsit dan dolomit lebih besar dari $50 \%$, ditambah mineral silikat, fosfat dan oksida (Simandl and Paradis, 2018). Mineral sebagai indikator pada kelompok karbonatit adalah uranothorianit, perovskit, piroklor, dan mineral yang mengandung unsur tanah jarang dalam kompleks karbonatit. Kadar rata-rata uranium berkisar antara kadar rendah hingga sangat rendah (5 s.d. $20 \mathrm{ppm}$ ) (IAEA, 2018). Cebakan uranium tipe intrusif subtipe plutonik - kelompok karbonatit tidak berpotensi terbentuk karena di Pulau Sulawesi tidak terdapat batuan karbonatit. 


\section{Cebakan Thorium Tipe Placer}

Cebakan thorium tipe placer terbentuk apabila di dalam batuan granitik terkandung mineral radioaktif kelompok thorium seperti monasit dan zirkon. Oleh karena proses pelapukan, erosi, transportasi dan sedimentasi maka mineral-mineral radioaktif kelompok thorium tersebut diendapkan sebagai endapan aluvial sungai maupun pantai karena mineral-mineral radioaktif tersebut merupakan mineral super stabil yang tahan terhadap pelapukan kimia dan fisika.

Hasil analisis petrografi dan analisis butir mineral berat batuan granitik di Sulawesi memperlihatkan bahwa mineral radioaktif yang terdapat pada batuan granitik terdiri dari zirkon, monasit, alanit, thorit, branerit dan apatit (Tabel 1).

Zirkon dan monasit (Cuney, 2014), alanit (Budzyn et al., 2017), thorit (IAEA, 2019) dan branerit (Costine et al., 2013) adalah mineral-mineral super stabil atau resisten terhadap pelapukan kimia maupun fisika sehingga uranium yang terkandung dalam mineral-mineral tersebut sulit terlarut oleh air (Cuney, 2014). Selain itu, apatit yang banyak ditemukan pada sampel juga merupakan salah satu mineral inang (host mineral) utama uranium dan thorium di kerak bumi (Hurley and Fairbairn, 1956).

Zirkon, monasit, alanit, thorit, branerit dan apatit cenderung akan tertransportasi oleh aliran sungai dan tersedimentasi menjadi endapan aluvial, delta dan pantai yang ada saat ini. Cebakan thorium tipe placer berpotensi terbentuk pada aliran sungai, delta dan pantai dengan sumber batuan granitik di Pulau Sulawesi.

Di Indonesia keterdapatan mineralisasi uranium pada batuan granitik dijumpai pada granit berumur Kapur di daerah Way Pubian Lampung. Nilai radioaktivitasnya $5.000 \mathrm{c} / \mathrm{s}$ dengan mineralnya berupa uraninit (Ngadenin dkk., 2020). Hasil pengukuran radioaktivitas batuan granitik di busur barat Pulau Sulawesi menunjukkan nilai berkisar antara $50 \mathrm{c} / \mathrm{s}$ hingga $1.200 \mathrm{c} / \mathrm{s}$. Nilai terendah $50 \mathrm{c} / \mathrm{s}$ terukur pada granodiorit di daerah Gorontalo sampel nomor 1 (Tabel 1 dan Gambar 2), sedangkan nilai tertinggi 1.200 $\mathrm{c} / \mathrm{s}$ terukur di daerah Kulawi sampel nomer 16 (Tabel 1 dan Gambar 2).

Dengan mengacu pada indikator keterdapatan mineralisasi uranium yang terdapat di Way Pubian, Lampung dengan radioaktivitas batuan $5.000 \mathrm{c} / \mathrm{s}$ maka di Pulau Sulawesi tidak terdapat indikator keterdapatan mineralisasi uranium pada batuan granitik.

\section{KESIMPULAN}

Berdasarkan pengukuran radioaktivitas, kadar uranium, pengamatan megaskopis, analisis petrografi dan analisis butir mineral berat dari batuan granitik di Pulau Sulawesi dapat disimpulkan bahwa cebakan mineral radioaktif yang berpotensi terbentuk adalah cebakan thorium tipe placer terutama pada aliran sungai, delta dan pantai yang bersumber dari kawasan batuan granitik. Secara konseptual daerah yang berpotensi diantaranya pesisir selatan Masamba dan sekitarnya serta pesisir utara Parigi dan sekitarnya (Gambar 2). Direkomendasikan untuk melakukan survei tinjau lanjutan untuk mengetahui keterdapatan, karakteristik dan sebaran cebakan mineral radioaktif di daerah tersebut.

\section{UCAPAN TERIMA KASIH}

Penulis mengucapkan terimakasih yang sebesar-besarnya kepada Bapak Ir. Yarianto Sugeng Budi Susilo, M. Si. selaku Kepala Pusat Riset dan Teknologi Bahan Galian Nuklir (PRTBGN - OR TN BRIN) serta Bapak Heri Syaeful, M.T. selaku Koordinator Bidang Eksplorasi yang telah mendukung penelitian ini sehingga penelitian dapat berjalan dengan lancar.

\section{DAFTAR PUSTAKA}

Bruneton, P., 2014. IAEA Classification of Uranium Deposits. URAM, IAEA. 
Budzyń, B., Harlov, D.E., Kozub-Budzyń, G., and Majka, J., 2017. Experimental Constraints on the Relative Stabilities of the Two Systems Monazite Allanite - Fluorapatite and Xenotime (Y,HREE)-Rich Epidote - (Y,HREE)Rich Fluorapatite in High $\mathrm{Ca}$ and $\mathrm{Na}-$ $\mathrm{Ca}$ Environments Under P-T Conditions of 200-1000 MPa and 450-750 ${ }^{\circ} \mathrm{C}$. Mineralogy and Petrology 110(6), April 2017, DOI: 10.1007/s00710-016-0464-0.

Costine, A., Nikoloski, A. N., Da Costa, M., Chong, K .F., and Hackl, R., 2013. Uranium Extraction from a Pure Natural Brannerite Mineral by Acidic Ferric Sulphate Leaching. Minerals Engineering, Volume 53, November 2013, Pages 84-90.

Cuney, M., 2014. Felsic Magmatism and Uranium Deposits. Bull. Soc. Geol. Fr.185,75-92.

Hakim, A.Y.A., 2017. Genesis of Orogenic Gold in the Latimojong District, South Sulawesi, Indonesia, PHd. Thesis, Montanuniversita, Leoben, Austria

Hasria, Idrus, A., and Warmada, I. W., 2017. The Metamorphic RocksHosted Gold Mineralization at Rumbia Mountains Prospect Area in the Southeastern Arm of Sulawesi Island, Indonesia. Journal of Geoscience, Engineering, Environment, and Technology Vol 02, No. 03.

Hurley, P. M. and Fairbairn H.W., 1956. Abundance and Distribution of Uranium and Thorium in Zircon, Sphene, Apatite, Epidote, and Monazite in Granitic Rocks. Trace Element Investigation Report 636, US Geological Survey, Washington.

International Atomic Energy Agency, 1998, (IAEA) - TECDOC -1035 Classification of Uranium Reserves / Resources, Vienna.

International Atomic Energy Agency, 2018, (IAEA) - TECDOC - 1842 :Geological Classification Of Uranium Deposits And Description Of Selected Examples, Vienna.
International Atomic Energy Agency, 2019, (IAEA) - TECDOC - 1892 : Thorium Resources as Co and By Products of Rare Earth Deposits, Vienna.

International Atomic Energy Agency, 2019, (IAEA)-TECDOC-1877 : World Thorium Occurences, Deposits and Resources, Vienna.

Jalil, A., Sutriyono, A., Widito dan Ngadenin, 1984, Laporan Akhir Prospeksi Pendahuluan Daerah Eksplorasi Sulawesi Sektor Pasangkayu, Laporan Internal PEPBN-BATAN, Jakarta, tidak dipublikasikan.

Kamaruddin, H., Ardiansyah I.K., Rosana, M. F., Sulaksana, N. dan Euis Tintin Yuningsih, E.T., 2018. Profil Endapan Laterit Nikel di Pomalaa, Kabupaten Kolaka, Provinsi Sulawesi Tenggara. Buletin Sumber Daya Geologi Volume 13, Nomor 2.

Kurniady, A. B., Hakim, F., Idrus, A., Warmada, I. W., Raharjanti, N. A., 2019. Karakteristik Petrologi dan Geokimia Batuan Granitoid Mamasa di Daerah Hahangan dan sekitarnya, Sulawesi Barat, Indonesia. Prosiding Seminar Nasional Kebumian Ke 12 Teknik Geologi UGM, Yogyakarta 5-6 September 2019.

Lintjewas, L., Setiawan, I. dan Al Kausar, A., 2019. Profil Endapan Nikel Laterit di Daerah Palangga, Provinsi Sulawesi Tenggara, J. Ris.Geo.Tam Vol. 29, No.1, Juni 2019 (91-104).

Maulana, A., Brocker, M., and Dan, W., 2020. Petrogenesis and Geochronology of Cenozoic Intrusion in the Poboya and Sassak gold and copper districts in the western Sulawesi, Indonesia : Implication for the Mineralization processes and magma sources. Journal of Asian Earth Science Vo. 193, May 2020.

Maulana, A., Imai, A., Van Leeuwen, T., Watanabe, K., Yonezu, K., Nakano, T., Boyce, A., Page, L., and Schersten, A., 2016. Origin and Geodynamic Setting of Late Cenozoic Granitoids in Sulawesi, Indonesia. Journal of Asia Earth Sciences, Vo. 124, 2016, p.102-125. 
Maulana, A., Watanabe, K., and Yonezu, K., 2016. Petrology and Geochemistry of Granitoid from South Sulawesi, Indonesia: Implication for Rare Earth Element (REE) Occurrences. International Journal of Engineering and Science Applications, IJEScA vol.3, 1, May 2016.

Maulana, A., Yonezu, K., and Watanabe, K., 2014. Geochemistry of Rare Earth Elements (REE) in the Weathered Crusts from the Granitic Rocks in Sulawesi Island, Indonesia. Journal of Earth Science, Vol. 25, No. 3, p. 460472, June 2014.

Ngadenin, Syaeful, H., Widana, K. S., Muhammad, A. G., Sukadana, I G., Trinopiawan, K., Prassanti, R., Anggraeni, M., Marisi, D. P., Fauzi, R., Pratiwi, F., 2020, 50 th Eksplorasi Uranium di Indonesia, BATAN Press, Jakarta.

Sampurno, P., Subiantoro, L., dan Widito, 1983, Laporan Akhir Prospeksi Pendahuluan Daerah Eksplorasi Sulawesi Sektor Gintu. Laporan Internal PEPBN-BATAN, Jakarta 1983, tidak dipublikasikan.

Sampurno, P., Singgih, M. D., Subiantoro, L., dan Subardjo, 1986, Laporan Akhir Prospeksi Pendahuluan Daerah Eksplorasi Sulawesi Sektor Marisa Limboto, Laporan Internal PEPBNBATAN, Jakarta 1986, tidak dipublikasikan.

Sarwiyana A., Mudiyo, S., Singgih, M. D., Tambunan, R., Riza, M. dan Paimin, 1980, Laporan Akhir Prospeksi Pendahuluan Daerah Eksplorasi Sulawesi Sektor Polewali-Mamasa, Laporan Internal PEPBN-BATAN, Jakarta 1980, tidak dipublikasikan.

Simandl, G. J. and Paradis S., 2018. Carbonatites: Related Ore Deposits, Resources, Footprint, and Exploration Methods. Applied Earth Science Volume 127, 2018.
Siregar, M., Sabarman, Suhartadi, Handoko. S., Harnadi, Suripto, Sularto, P., Marzuki, A., 1983, Laporan Akhir Prospeksi Pendahuluan Detil Eksplorasi Sulawesi Luwu Utara, Laporan Internal PEPBN-BATAN, Jakarta 1983, tidak dipublikasikan.

Soetarno, D., Paimin, Widito dan Ngadenin, 1983, Laporan Akhir Prospeksi Pendahuluan Daerah Eksplorasi Sulawesi Sektor ParigiBangkir, Laporan Internal PEPBNBATAN, Jakarta 1983, tidak dipublikasikan.

Sompotan, A. F., 2012. Struktur Geologi Sulawesi, Perpustakaan Sains Kebumian Institut Teknologi Bandung.

Syaeful, H., Sukadana, I.G., dan Sumaryanto, A., 2014. Radiometric Mapping for Naturally Occuring Radioactive Materials (NORM) Assesment in Mamuju, West Sulawesi, Atom Indonesia Vol. 40, No. 1, BATAN, Jakarta.

Thamsi, A. B., 2016. Estimasi Cadangan Terukur Endapan Nikel Laterit Cog 2,0\% Menggunakan Metode Inverse Distance pada PT. Teknik Alum Service, Blok X. Jurnal Geomine, Vol 4, No. 3: Desember 2016.

Van Leeuwen, T. M. and Pieters, P. E., 2011. Mineral Deposits of Sulawesi. Proceedings of The Sulawesi Mineral Resources 2011 Seminar MGEI-IAGI 28-29 November 2011, Manado, North Sulawesi, Indonesia.

White, L. T., Hall, R., Amstrong, R. A., Barber, A. J., Bou, M., Fadel, D., Baxter, A., Wakita, K., Manning, C., and Soesilo, J., 2017. The Geological History of the Latimojong Region of Western Sulawesi, Indonesia. Journal of Asian Earth Sciences Vol. 138, 1 May 2017, p.72-91.

Watkinson, I. M., 2011. Ductile Flow in the Metamorphic Rocks of Central Sulawesi. Geological Society of London, Special Publication, 355, 157-176, 27 June 2011. 


\section{MAKALAH ILMIAH}

Widodo dan Ngadenin, 2020. Studi Keterdapatan Mineral Radioaktif pada Batuan Granitik Tersier dan Batuan Malihan Kapur di Masamba, Sulawesi Selatan. Prosiding Seminar Nasional Teknologi Energi Nuklir 2020, Serpong, 18 November 2020.

Zhang, Q., Liu, Y., Wu, Z., Huang, H., Li, K., and Zhou, Q., 2019. Late Triassic Granites from the Northwestern Margin of the Tibetan Plateau, the Dahongliutan Example: Petrogenesis and Tectonic Implications for the Evolution of the Kangxiwa PalaeoTethys. International Geology Review Volume 61, 2019,p.175-194.
Zhao, K. D., Jiang, S. Y., Dong, C. Y., Chen, W. F., Chen, P. R., Ling, H. F., Zhang, J., and Wang, K. X., 2011. Uranium Bearing and Barren Granites from the Taoshan Complex, Jiangxi Province, South China : Geochemical and Petrogenetic Discrinimation and Exploration Significance. Journal of Geochemical Exploration 110 (2011) 126-135.

Zhao, K. D., Li, J. R., Ling, H. F., Chen, P. R., Chen, W., F., and Sun, T. , 2013. Geochronology, Geochemistry and Petrogenesis of Two-Stage Indosinian Granites from the Xiajiang Uranium Ore Deposit, Jiangxi Province: Implication for Indosinian Tectonics and Genesis of Uranium Bearing Granites in South China. Acta Petrol. Sin., vol. 29, no. 12, pp. 4349-4361, 2013.

\begin{tabular}{|ll|}
\hline Diterima & $: 5$ September 2021 \\
Direvisi & $: 5$ Oktober 2021 \\
Disetujui & $:$ 15 November 2021 \\
\hline
\end{tabular}

